Francois Njock Bayock ${ }^{1 \mathrm{a}}$, Paul Kah $^{1 \mathrm{~b}}$, Belinga Mvola ${ }^{1 \mathrm{c}}$, Pavel Layus $^{1 \mathrm{~d}}$, Xiaoyu Cai $^{2 \mathrm{e}}$

\title{
Characterization of bainite-ferrite structures formed on the heat- affected zone of a dissimilar welds of high-strength steel (S700MC/S960QC) and their dependency on cooling time
}

\section{Karakterizacija beinitno-feritnih struktura formiranih u zoni uticaja toplote zavarenih spojeva različitih čelika visoke čvrstoće (S700MC/S960QC) i njihova zavisnost od brzine hlađenja}

\author{
Originalni naučni rad / Original scientific paper \\ UDK / UDC: \\ Prezentovano u okviru 72. IIW godišnje Skupštine i međunarodne \\ konferencije održane u Bratislavi-Slovačka 07-12. Jula 2019 \\ Rad primljen / Paper received: \\ Oktobar 2020. \\ Prevod izvornog rada na srpski jezik; Z. Odanović
}

Ključne reči: Zavarivanje različitih materijala, S960QC, S700MC, zrnasti beinit, temperovani martenzit

\begin{abstract}
Modern steel structures and joints must satisfy various increasingly demanding requirements such as high yield strength, improved cross section to mass ratio, and desirable ductile-to-brittle transition properties. Consequently, joining different types of high-strength steels has become an attractive option from the cost perspective and for weight and corrosion reduction. In dissimilar welding, however, there remains a need for better understanding of discrepancies in microstructure formation resulting from asymmetric heat distribution. In this study, a characterization of the transformation of bainite, ferrite, and martensite in the microstructure of the heat affected zone (HAZ) formed by a cooling time of $10 \mathrm{~kJ} / \mathrm{cm}$ of heat input was carried out for dissimilar high-strength joint steels
\end{abstract} (S700MC/S960QC). The characterization was performed by scan electron microscopy (SEM) sampling, the images of which were analyzed by ImageJ Pro and evaluated by volume fraction of block - like granular bainite (GB). The alloy elements composition close to the fusion line of both materials was then assessed using energydispersive X-ray spectroscopy (EDS). The results showed a strong presence of GB, which had about $70 \%$ volume fraction in S700MC at $615{ }^{\circ} \mathrm{C}$, and which comprised formations of lower bainite and retained austenite $(R A)$ at $420^{\circ} \mathrm{C}$. The presence of $55 \%$ block GB was observed at $470{ }^{\circ} \mathrm{C}$ in S960QC, which was caused by the formation of tempered martensite (TMA) at $400^{\circ} \mathrm{C}$. Presence of $1.3 \mathrm{Ni}$,

\author{
Adresa autora / Author's address: \\ ${ }^{1}$ Mechanical Engineering, Welding Technology Laboratory, \\ Lappeenranta-Lahti University of Technology, Lappeenranta, \\ Finland, ${ }^{a}$ francois.njock.bayock@lut.fi, ${ }^{b}$ paul.kah@lut.fi, \\ ceric.mvola.belinga@lut.fi, ${ }^{d}$ pavel.layus@lut.fi \\ ${ }^{2}$ State Key Laboratory of Welding and Joining, Harbin Institute \\ of Technology, Harbin Shi, China \\ exycai@hit.edu.cn
}

Keywords: dissimilar welding, S960QC, S700MC, granular bainite, tempered martensite

\section{Rezime}

Moderne čelične structure i spojevi moraju da zadovolje različite zahteve kao što je visoki napon tečenja, visok odnos poprečnog preseka prema masi komada, i zadovoljavajući odnos osobina prelaznih osonina plasičnosti i krtosti. Na taj način, spajanje različitih tipova čelika visoke čvrstoće je postalo atraktivno sa stanovišta troškova i smanjenja težine i korozije. Pri zavarivanju različitih materijala, postoji potreba za bolje razumevanje odstupanja nastajanja mikrostruktura kao rezultat asimetrične raspodele toplote. $U$ ovoj studiji, karakterizacija transformacije beinita, ferita i matrenzita u mikrostrukturi zone uticaja toplote (ZUT), nastale hlađenjem pri unosu toplote od 10 $\mathrm{kJ} / \mathrm{cm}$, je izvedena za spojeve različitih čelika visoke čvrstoće (S700MC/S960QC).

Karakterizacija je izvršena skenirajućom elektronskom mikroskopijom (SEM), analiza slika je vršena sa softverom ImageJ Pro i određivan je udeo zapreminskog udela faza, kao što je zrnasti beinit (GB). Sadržaj legirajućih elemenata uz liniju spoja oba materijala je određen primenom energo disperzivne spektroskopije $X$ zracima (EDS). Rezultati pokazuju značajno prisustvo GB, koji je imao oko $70 \%$ zapreminskog udela u čeliku S700MC pri $615{ }^{\circ} \mathrm{C}$ i koji se sastoji od donjeg beinita i zaostalog austenite (RA) na $420^{\circ} \mathrm{C}$. Prisustvo od $55 \%$ GB je konstatovano pri $470^{\circ} \mathrm{C}$ kod čelika S960QC, koje je prouzrokovano stvaranjem temperovanog martenzita (TMA) na 400 ${ }^{\circ} \mathrm{C}$. Prisustvo $1.3 \mathrm{Ni}, 0.4 \mathrm{Mo}$, i $1.6 \mathrm{Mn}$ u zoni porasta 
$0.4 \mathrm{Mo}$, and $1.6 \mathrm{Mn}$ in the coarse grain heat affected zone (CGHAZ) of S700MC confirmed the risk of brittle failure on the S700MC side due to the high presence of carbide and ferrite in the GB.

\section{Introduction}

The specificitions of new steels, especially high strength, provide the desirable qualities of strength, hardness, and ductility at reduced weight ,which significantly extends the range of possible applications. For example, in assembly of some parts of vehicle structures, there is the challenge of maintaing structural strength while simultaeously reducing the mass of the vehicle to improve fuel consumption and environmental suistainability. Dissimilar welds between high strength steels with a maximum yield strength of $700 \mathrm{MPa}$ and yield strength of $960 \mathrm{MPa}$, would meet these aims of reducing mass while maintaining strength. However, joining two materials with different thermo-mechanical, chemical and manufacturing properties has an exceptional character, and requires thorough analysis of the welding processes used, and the effects of weld joint geometryand choice of filler material. Investigation of the feasability of submitting such materials to pre and post weld heat treatment while maintaining their benefical chemical and mechanical characteristics is a critical task[1-3]. Welding a material such as S700MC [4], which in its production has already undergone heat treatment, and maintaining its mechanical, and chemical characteristics even after having experienced a thermal shock with S960QC is a great challenge. S960QC, whose microstructure also has low alloy elements, exhibits thermal sensitive behavior and thus analysis of essential microstructure (phase transformation) change is required, particularly in the heat affected zone during the welding process. The microstructuralcomposition of S700MC, consists mainly of bainite-ferrite (BF), and S960QC, is composed of bainite martensite (BM). During cooling process, displacement of phases transformations occurs around and even in the austenite grains. Transformation is observed from ferrite to bainite and, bainite to martensite, with some incomplete changes called retained austenite (RA) $[7,8]$. Much research has investigated characterization of the microstructure of steels with a low percentage of carbon. Most such research applies heat treatment to these steels and analyzes the behavior of the phase transformation of bainite, ferrite, and martensite. In most cases, the constituents of the austenite grains are identified and the volume fraction of the phase transformation then determined. These tranformations have an zrna u zoni uticaja toplote (CGHAZ) kod čelika S700MC potvrđuje rizik nastajanja krtog loma na strani čelika S700MC, zbog visokog sadržaja karbida i ferita u GB.

\section{Uvod}

Karakteristike novih vrsta čelika, posebno visoke čvrstoće, obezbeđuju željene osobine visoke čvrstoće, tvrdoće i plastičnosti sa smanjenjem težine, čime se proširuje mogućnost njihove primene. $\mathrm{Na}$ primer, pri izradi nekih delova konstrukcija vozila, poseban izazov predstavlja zadržavanja čvrstoće konstrukcije, uz istovremeno smanjuje mase vozila, a sve da bi se smanjila potrošnja goriva i poboljšala zaštita životne okoline.

Zavarivanjem čelika visoke čvrstoće sa maksimalnom granicom tečenja od $700 \mathrm{MPa} i$ čelika sa granicom tečenja od $960 \mathrm{MPa}$, omogućava se zadovoljavanje zahteva za smanjenjem težine sa zadržavanjem čvrstoće. Međutim spajanje dva materijala sa različitim termo-mehaničkim, hemijskim i proizvodnim osobinama, zahteva posebnu pažnju kroz analizu i izbor procesa zavarivanja i uticaja geometrije zavarenog spoja i izbora dodatnog materijala. Ispitivanja izvodljivosti i podvrgavanja takvih materijala prethodnoj i naknadnoj termičkoj obradi uz zadržavanje povoljnih hemiskih i mehaničkih karakteristika je poseban izazov [1-3].

Zavarivanje materijala kao sto je čelik S700MC [4], koji se tokom proizvodnje podvrgava termičkoj obradi i zadržava svoje mehaničke i hemijske karakteristike čak i ako se izlaže termičkim šokovima, sa čelikom S960QC, je veliki izazov. Čelik S960QC, čija mikrostruktura takođe sadrži legirajuće elemente, pokazuje termičku osetljivosti, što zahteva analizu promene osnovne mikrostrukture i faznih transformacija, posebno u zoni uticaja toplote za vreme procesa zavarivanja. Mikrostruktura čelika S700MC se uglavnom sastoji od beinita i ferita (BF), a mikrostruktura čelika S960QC se sastoji od beinita i martenzita, sa nepotpuno transformisanom fazom nazvanom zaostali austenit (RA) [7,8].

Mnogi istraživači su ispitivali i vršili karakterizaciju mikrostruktura čelika sa niskim sadžajem ugljenika. $U$ većini takvih ispitivanja primenjivana je termička obrada na čelicima i analizirano su fazne transformacije beinita, ferita i martenzita. $U$ većini slučajeva su identifikovani konstituenti austenitnih zrna i određen je zapreminski udeo faza pri transformaciji. Ove transformacije imaju važan uticaj na ponašanja prelaska plastičnog ka krtom stanju zavarenog spoja.

U ovoj studiji, zavareni uzorci su pažljivo pripremani i zatim analizirani na SEMu, da bi se dobile 
important impact on the ductile to brittle factor of the weld joint. In this study, welded samples is carefully prepared, and then analyzed by sampling using SEM images, to evaluate the composition of the microstructures of the weld joint (CGHAZ and FGHAZ). Determination of volume fractions of the differents grain surface was done using ImageJ Pro software. EDS analysis of the welded samples was used to determine the composition of alloy elements forming microstructures in the CGHAZ and for analysis of fusion line between the base metal and filler material. This analysis allowed the correlation between the cooling time (t8/5), the microstructure behavior, and the mechanical properties of the weld joint to be determined.

\section{Experimental Section}

\subsection{Materials}

Dissimilar High-strength steels, namely S700MC and S960QC, and filler material X96, were welded as part of this investigation. The chemical composition of both steels and filler material is given in Table 1, which includes also the welding parameters of the welding process used. The GMAW welding was done using a robot system with protective shielding of $\mathrm{Ar}+18 \% \mathrm{CO} 2$. The welded specimens had dimensions of $300 \times 200 \times 8$ $\mathrm{mm}$, and the weld was a $\mathrm{V}$ joint $\left(60^{\circ}\right)$ with $2 \mathrm{~mm}$ gap. Analysis of heat effects was carried out by varying the heat source parameters current (I), voltage $(V)$, welding speed (s) and heat input $(\mathrm{Q})$. The welding process was carried out according to the international standards ISO 1561-1-2017. The automatic robotic welding process equipment comprising an ABB IRC robot control unit, MAG torch and data acquisition control unit used in this study is illustrated in Fig. 1. A laser sensor was installed in the welding equipment to record thermal transfer data for calculation of the cooling time (t8/5) from $800{ }^{\circ} \mathrm{C}$ to $500{ }^{\circ} \mathrm{C}$. In the laser thermal control process, the recorded cooling time was $t 8 / 5=31 \mathrm{~s}$. The prepared samples were placed in the SEM equipment for imaging of areas of the HAZ (WM, CGHAZ and FGHAZ) of the materials. 15.0 $\mathrm{kV}$ magnification was used and $50.0 \mu \mathrm{m}$ definition to enable clear identification of microstructure growth in the austenite grain. ImageJ Pro software was used to determine the volume fraction of phase transformations (GB, TMA, and RA) inside the austenite grain. Energydispersive X-ray spectroscopy (EDS) was applied to evaluate the concentration of alloyin elements close to the fusion line of both material. Analysis focused mainly on $\mathrm{Mn}, \mathrm{Ni}, \mathrm{Mo}$, which have an impact on hardness in the HAZ of the weld joint. mikrostrukture zavarenog spoja (zona porasta zrna u ZUTu - CGHAZ i finozrna zona u ZUTu FGHAZ). Određivanje zapreminskog udela različitih površina zrna je izvođena primenom softvera ImageJ Pro. EDS analiza zavarenih uzoraka je primenjena za određivanje sadžaja legirajućih elemenata koji formiraju mikrostrukture u zoni porasta zrna CGHAZ i za analizu linije spoja između osnovnog metala i dodatnog metala. Ova analiza je omogućavala uspostavljanje korelacije između vremena hlađenja $\left(t_{8 / 5}\right)$, ponašanja mikrostruktura i mehaničkih osobina zavarenog spoja.

\section{Experimentalni deo 2.1 Materijali}

Kao deo ovih istraživanja zavarivani su različiti čelici visoke čvrstoće i to čelik S700MC i S960QC sa dodatnim materialom X96. Hemijski sastav oba čelika i dodatnog materijala su prikazani u Tabeli 1., gde su prikazani i parametri procesa zavarivanja. Primenjen je postupak zavarivanja MAG sa zaštitnim gasom $\mathrm{Ar}+18 \% \mathrm{CO}_{2}$. Uzorci za zavarivanje su imali dimenzije $300 \times 200 \times 8 \mathrm{~mm}$, sa $V$ žljebom $\left(60^{\circ}\right)$ i zazorom od $2 \mathrm{~mm}$. Analiza toplotnih efekata je vršena promenom parametara izvora toplote kao što su jačina struje (I), napon (V), brzina zavarivanja (s) i unos toplote (Q). Proces zavarivanja vršen je u skladu sa internacionalnim standardom ISO 1561-1-2017.

Automatska robotizovana oprema za zavarivanje sastojala se od ABB IRC kontrolne jedinice za robota, zatim MAG gorionika i kontrolne jedinice za akviziciju podataka, što je prikazano je na Slici 1 . Laserski sensor je bio instaliran na opremu za zavarivanje da bi beležio podatke prenosa toplote za proračun vremena hlađenja $\left(t_{8 / 5}\right)$ od $800^{\circ} \mathrm{C}$ do $500^{\circ} \mathrm{C}$ i zabeleženo je vreme hlađenja od $t_{8 / 5}=31 \mathrm{~s}$. Pripremljeni uzorci su montirani u opremu uređaja SEMa, da bi se posmatrale oblasti ZUTa materijala (WM, CGHAZ i FGHAZ). $15.0 \mathrm{kV}$ uveličanje je korišćeno i rezolucija od $50.0 \mu \mathrm{m}$ omogućavala je jasnu identifikaciju rasta mikrostrukturnih komponenti u austenitnim zrnima. ImageJ Pro softver je korišćen za određivanje zapreminskog udela faznih transformacija (GB, TMA, and RA) unutar austenitnih zrna. Energo disperzivna spektroskopija X zracima (EDS) je primenjena za određivanje koncentracije legirajućih elemenata uz liniju spoja kod oba materijala. Analiza je prvenstveno primenjena na $\mathrm{Mn}, \mathrm{Ni}$ i Mo, koji imaju uticaj na tvrdoću u ZUTu zavarenog spoja. 


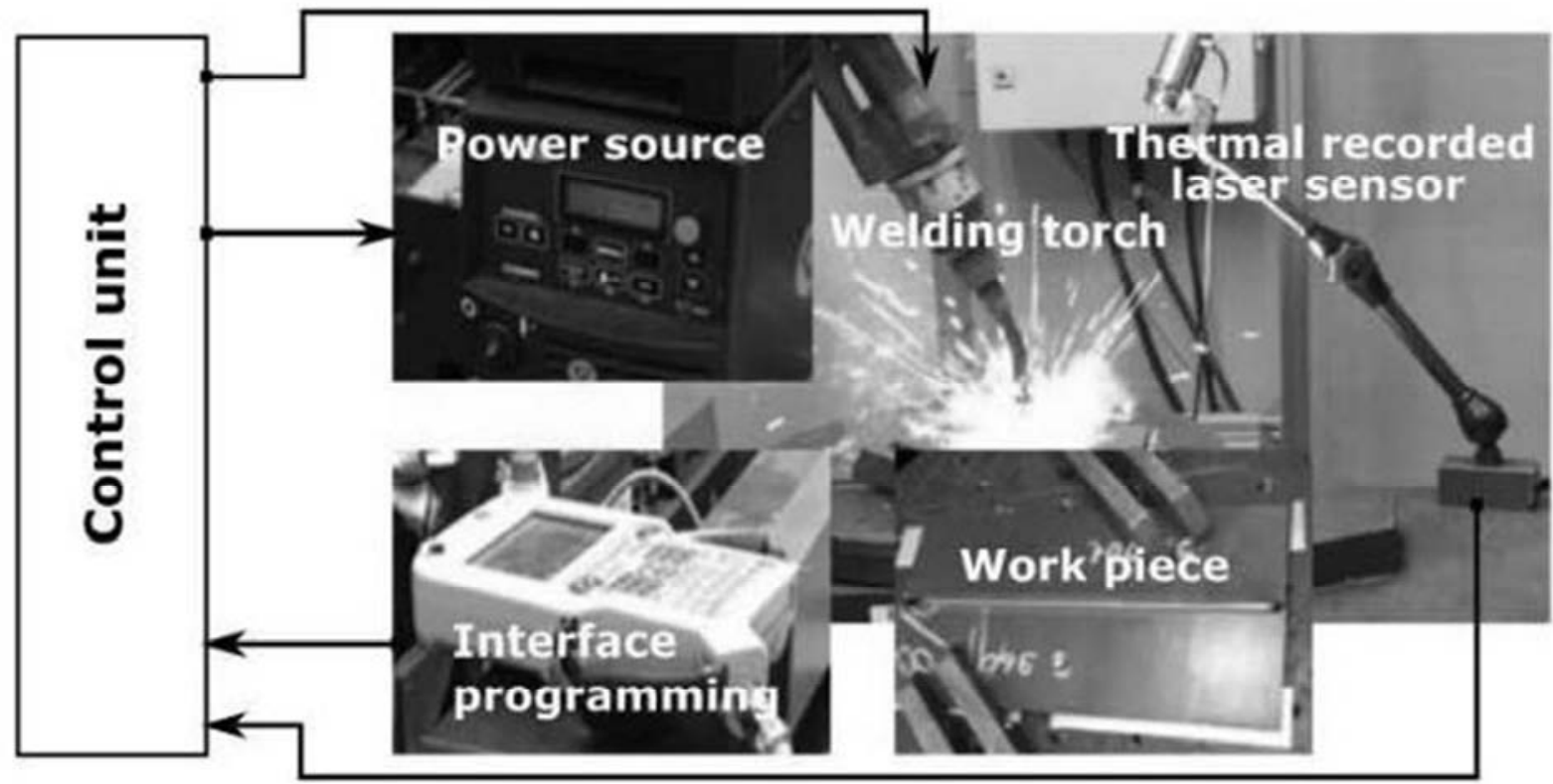

Figure 1. Automatic GMAW process using an ABB IRC 5 Robot

Slika 1. Automatizovani MAG proces uz primenu $A B B$ IRC 5 robota

Table 1. Chemical composition and mechanical properties of S700MC and S960QC steels and filler material X96 Tabela 1. Hemijski sastav i mehaničke osobine čelika S700MC i S960QC i dodatnog materijala X96

\begin{tabular}{|c|c|c|c|c|c|c|c|c|c|c|c|c|c|c|c|}
\hline \multicolumn{16}{|c|}{$\begin{array}{l}\text { Chemical composition of base and filler material, Wt. \% } \\
\text { Hemijski sastav osnovnih i dodatnih materijala, zapr. \% }\end{array}$} \\
\hline Materials & C & $\mathrm{Si}$ & Mn & $\mathrm{Al}$ & B & Nb & $\mathrm{Ti}$ & $\mathbf{V}$ & $\mathrm{Cu}$ & $\mathrm{Cr}$ & $\mathrm{Ni}$ & Mo & $\mathbf{N}$ & $\mathbf{P}$ & $S$ \\
\hline S700MC & 0.056 & 0.16 & 1.18 & 0.027 & 0.002 & 0.044 & 0.12 & 0.006 & 0.02 & 0.062 & 0.06 & 0.01 & 0.005 & 0.01 & 0.005 \\
\hline S960QC & 0.09 & 0.021 & 1.05 & 0.03 & 0.002 & 0.03 & 0.032 & 0.008 & 0.025 & 0.82 & 0.04 & 0.04 & - & 0.01 & 0.004 \\
\hline $\begin{array}{l}\text { Filler / } \\
\text { Dodatni } \\
\text { material }\end{array}$ & 0.12 & 0.8 & 1.9 & & - & - & & - & $\leq 0.30$ & 0.45 & 2.35 & 0.55 & & - & - \\
\hline \multicolumn{16}{|c|}{$\begin{array}{l}\text { Welding parametars } \\
\text { Parametri zavarivanja }\end{array}$} \\
\hline \multicolumn{4}{|c|}{$\begin{array}{l}\text { Welding current } \\
\text { Struja zavarivanja }[A]\end{array}$} & \multicolumn{2}{|c|}{$\begin{array}{l}\text { Arc / Napon } \\
\text { [V] }\end{array}$} & \multicolumn{2}{|c|}{$\begin{array}{c}\text { Welding } \\
\text { speed } \\
\text { Brzina } \\
\text { zavarivanja } \\
\text { [cm/min] }\end{array}$} & \multicolumn{2}{|c|}{$\mathrm{Q}[\mathrm{kJ} / \mathrm{cm}]$} & \multicolumn{2}{|c|}{$\begin{array}{c}\text { Torch Angle } \\
\text { Ugao } \\
\text { gorionika }\end{array}$} & \multicolumn{2}{|c|}{$\begin{array}{l}\text { Shielding } \\
\text { Zaštitni gas }\end{array}$} & \multicolumn{2}{|c|}{$\begin{array}{c}\text { Distance } \\
\text { contact tube } \\
\text { Rastojanje } \\
\text { do radnog } \\
\text { komada }\end{array}$} \\
\hline \multicolumn{4}{|c|}{225} & \multicolumn{2}{|c|}{25.3} & \multicolumn{2}{|c|}{62.1} & \multicolumn{2}{|c|}{$\begin{array}{l}7 \mathrm{~kJ} / \mathrm{cm} \mathrm{P} 1 \\
10 \mathrm{~kJ} / \mathrm{cm} \\
\mathrm{P} 2\end{array}$} & \multicolumn{2}{|c|}{$5^{\circ}$} & \multicolumn{2}{|c|}{$\begin{array}{l}\mathrm{Ar}^{+} 18 \% \\
\mathrm{CO}_{2}\end{array}$} & \multicolumn{2}{|c|}{$18 \mathrm{~mm}$} \\
\hline
\end{tabular}

\subsection{Experimental procedure}

CCT diagrams drawn based on litterature $[13,14]$ and recorded thermal transfer data allowed identification of phase transformation in the microstructure of the WM, CGHAZ, and FGHAZ of both materials and filler material. Fig. 2a presents the CCT diagram for S960QC showing the cooling time of the welded sample which determines the phase transformations subsequently observed in the microstructure. The curve for S960QC indicates three transformation points: $550{ }^{\circ} \mathrm{C}, 470{ }^{\circ} \mathrm{C}$ and $400^{\circ} \mathrm{C}$. Following the liquefaction phase, cooling to $550{ }^{\circ} \mathrm{C}$ corresponds to the start of bainite

\subsection{Eksperimentalna procedura}

$\mathrm{KH}$ dijagrami su zasnovani na podacima iz literature $[13,14]$ i sa zabeleženim podacima prenosa toplote omogućavaju identifikaciju faznih transformacija u mikrostrtukturi u oblasti zavarenog spoja, kao što su WM, CGHAZ, i FGHAZ za oba materijala i za dodatni material. Slika 2a predstavlja dijagram KH za čelik S960QC koji prikazuje vreme hlađenja zavarenog uzorka koji određuje fazne transformacije koje se opažaju u strukturi. Kriva za čelik S960QC pokazuje tri transformacione tačke: $550^{\circ} \mathrm{C}, 470^{\circ} \mathrm{C}$ and $400^{\circ} \mathrm{C}$. Prateći stvaranje faza, hlađenje do $550^{\circ} \mathrm{C}$ odgovara početku beinitne 
transformation and $470{ }^{\circ} \mathrm{C}$ marks the end of the transformation. The end of bainite transformation corresponds to beginning of the martensite transformation, which ends at a temperature estimated at $400{ }^{\circ} \mathrm{C}$. Fig. $2 \mathrm{~b}$ presents the CCT diagram for S700MC showing the cooling time curve of the weld. The following temperatures were defined as those triggering phase transformation in microstructures, particularly in the HAZ. The first phase transformation (ferrite) starts at $670{ }^{\circ} \mathrm{C}$ and ends at $615{ }^{\circ} \mathrm{C}$, followed by the bainite transformation, which starts at $615^{\circ} \mathrm{C}$ and ends at about $500{ }^{\circ} \mathrm{C}$. Observation of the curves of the two CCT diagrams indicates that there may be incomplete transformations because differences in temperatures of the transformations in the differents steels are very small.

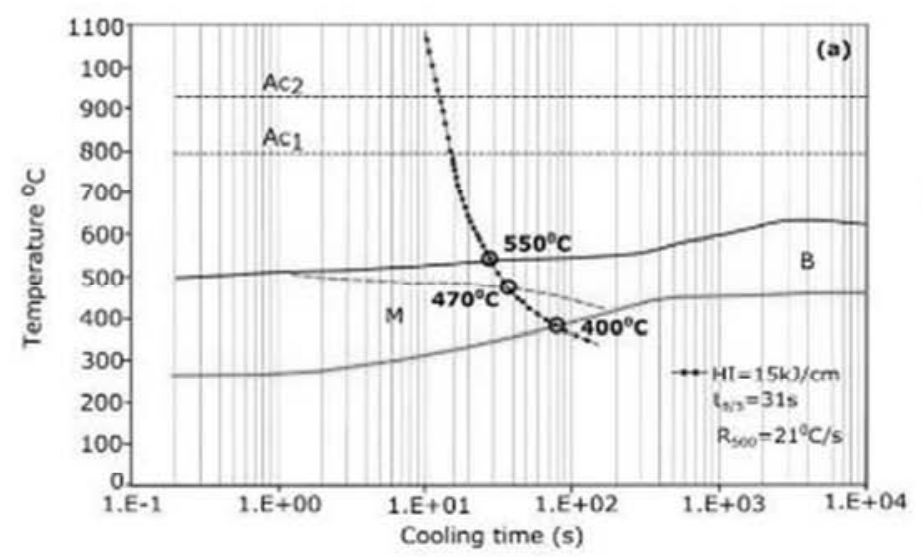

transformacije, a $470^{\circ} \mathrm{C}$ označava kraj transformacije. Kraj beinitne transformacije predstavlja početak martenzitne transformacije, koja se završava na temperature od $400^{\circ} \mathrm{C}$. Slika 2b predstavlja $\mathrm{KH}$ dijagram za čelik S700MC koji pokazuje krivu hlađenja zavarenog spoja. Sledeće temperature se definišu kao inicijatori faznih transformacija posebno u ZUT-u. Prva fazna transformacija (ferita) počinje na $670^{\circ} \mathrm{C}$ i završava se na $615^{\circ} \mathrm{C}$, na koju se nadovezuje beinitna transformacija, koja počinje na $615^{\circ} \mathrm{C}$ i završava se na oko $500^{\circ} \mathrm{C}$. Razmatranjem krivih ova dva $\mathrm{KH}$ dijagrama, ukazuje da je možda nepotpuna transformacija zbog razlika u temperaturama transformacija kod ovih različitih čelika, ali je ona vrlo mala.

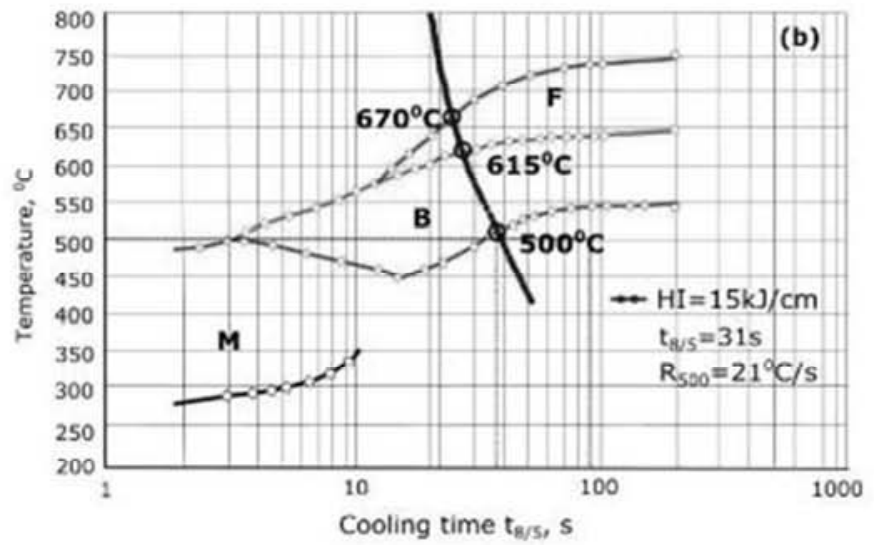

Figure 2. CCT diagrams obtained by JMat Pro software: (a) CCT diagram for S960QC; (b) CCT diagram for S700MC

Slika 2. KH dijagrami dobijeni softverom JMat Pro: a) KH dijagram za čelik S960QC, b) KH dijagram za čelik S700MC

\section{Results and Discussion}

Fig. 3 shows SEM images of the CGHAZ and FGHAZ of S700MC, S960QC and WM of the weld joint of the dissimilar HSS S700MC/S960QC weld. Fig. 3(a) presents an SEM image of the CGHAZ of S700MC; Fig. 3(b) an SEM image of the CGHAZ of S960QC; Fig. 3(c) a macro image of the welded sample showing the mapping area; and Fig. 3(d) an SEM micrograph of the WM. Using mapping of Fig. $3(a)$, it can be seen that the cooling temperature of $615{ }^{\circ} \mathrm{C}$ temperature of $615{ }^{\circ} \mathrm{C}$ corresponds to the ferrite-bainite phase transformation. From the image, it is difficult to draw clear conclusions in terms of the type of bainite or ferrite. Using mapping of Fig. 3(b), the micrograph of the CGHAZ of S960QC cooling temperature of $470{ }^{\circ} \mathrm{C}$ for the transformation of GB composed of ferrite cementite inside bainite transformations. The microstructure of the WM, Fig.3(d), has a morphology of a fine line showing formation of Widmanstätten ferrite (WF) with some

\section{Rezultati i diskusija}

Slika 3 prikazuje izgled mikrostruktura na SEM mikroskopu zona CGHAZ i FGHAZ, čelika S700MC, S960QC i metala šava (WM) zavarenog spoja različitih čelika HSS S700MC/S960QC. Na Slici 3a) predstavljen je SEM izgled zone CGHAZ čelika S700MC, Slika 3b) daje izgled na SEMu zone CGHAZ čelika S960QC; Slika 3c) makro izgled zavarenog uzorka sa mestima analize; i na Slici 3d) prikazan je izgled na SEMu metala šava. Primenom mapiranja sa Slike 3a), može se videti da temperatura hlađenja $61{ }^{\circ} \mathrm{C}$ odgovara faznoj feritno-beinitnoj transformaciji. Sa slike je teško jasno zaključiti o tipovima beinita ili ferita. Primenom mapiranja sa Slike $3 \mathrm{~b}$ ), mikrostruktura zone CGHAZ čelika S960QC, za temperaturu hlađenja od $470^{\circ} \mathrm{C}$ za transformaciju GB, se sastoji od feritnog cementita unutar transformisanog beinita. Mikrostruktura metala šava (WM), Slika 3d), ima fino linijsku morfologiju koja pokazuje 
surfaces with isolated cylindrical and square shapes, which were identified as acicular ferrite (AF). The same process was applied to the images on the right side of Fig. 3 with the difference that the mapping was performed on the FGHAZ, which allowed identification of the austenite grains and some phase transformations inside the grains. The different morphologies were characterized as bainite, ferrite, martensite and cementite, and retained austenite was observed in these grains. By observing austenite grains of S700MC at $500{ }^{\circ} \mathrm{C}$ Fig. 3(f), transformation of GB is detected with RA, which is identified as a dark area inside the austenite grain. transformation of bainite to RA is observed on austenite grains of S960QC at $400{ }^{\circ} \mathrm{C}$, where RA is transformed to TMA.
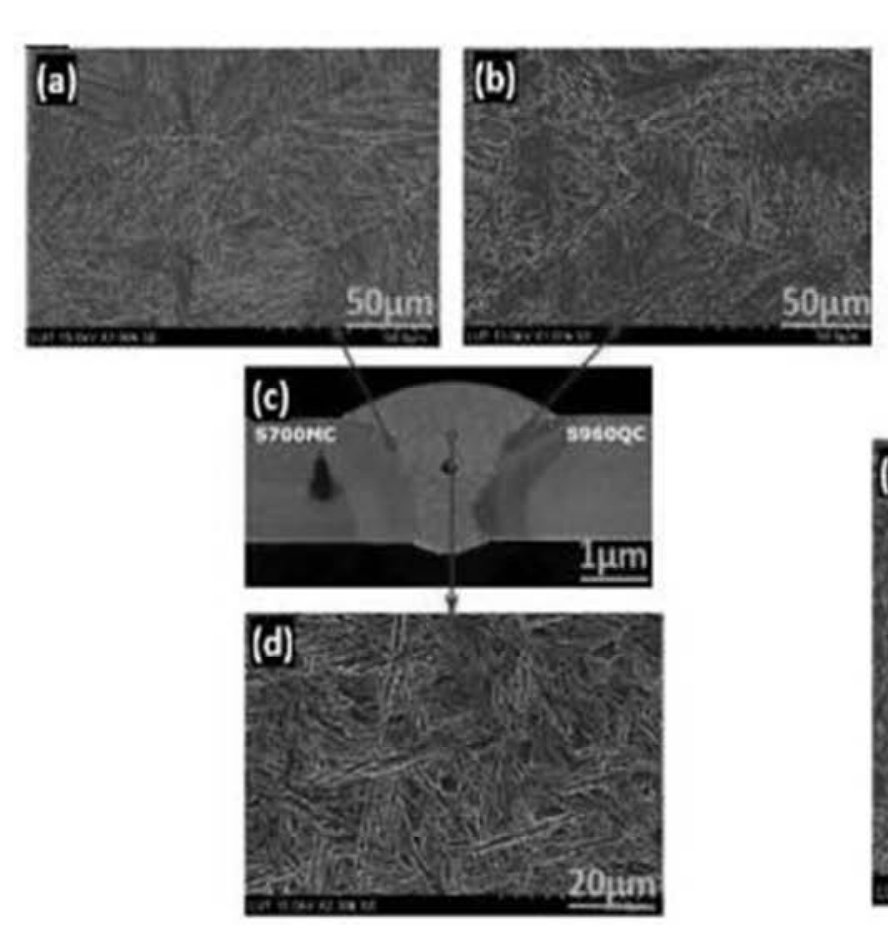

formiranje Widmanstätten-ovog ferita (WF), sa ponekim izolovanim cilindričnim i kvadratnim oblicima, koji su identifikovani kao acirkularni ferit (AF). Identična procedura je primenjena na mikrostrukturama na desnoj strani Slike 3, sa razlikom da je mapiranje izvršeno na fino zrnastoj zoni FGHAZ, koja omogućava identifikaciju austenitnih zrna i delom faznih transformacija unutar zrna. Različite morfologije se karakterišu kao beinit, ferit, martenzit i cementit, i zaostali austenit je uočen u tim zrnima. Posmatranjem austenitnih zrna čelika S700MC na $500^{\circ} \mathrm{C}$ Slika $3 f$ ), transformacija zrnastog beinita (GB) je otkrivena sa RA, koji je identifikovan kao tamna oblast unutar austenitnih zrna. Transformacija beinita u RA je uočena na austenitnim zrnima čelika S960QC na $400^{\circ} \mathrm{C}$, gde se RA transformiše u TMA.

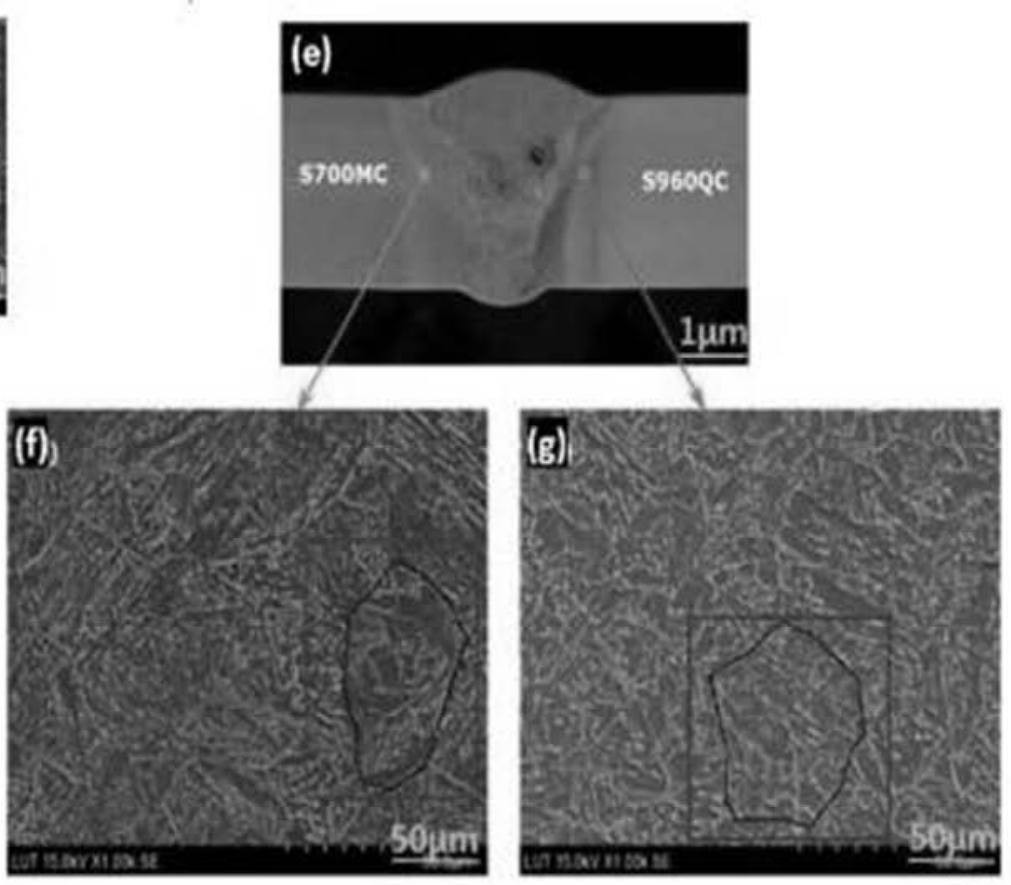

Figure 3. Macro image of the sample and SEM images of the CGHAZ and FGHAZ of S700MC, S960QC and WM. (a) SEM image of CGHAZ of S700MC; (b) SEM image of CGHAZ of S960QC; (c) Macrograph of the sample; (d) SEM image of WM; (e) Macrograph of the sample; (f) SEM image of FGHAZ of S700MC; (g) SEM image of FGHAZ of S960QC

Slika 3. Makro izgled uzorka i SEM slike zona CGHAZ i FGHAZ čelika S700MC, S960QC i WM. (a) SEM slika zone CGHAZ čelika S700MC; b) SEM slika zone CGHAZ čelika S960QC; c) Makro struktura uzorka zavarenog spoja; (d)

SEM slika zone metala šava WM; (e) Makro struktura uzorka zavarenog spoja; (f) SEM slika zone FGHAZ čelika

\subsection{Microstructural features}

S700MC; (g) SEM slika zone FGHAZ čelika S960QC

The microstructure composition of austenite grains in the FGHAZ of S700MC was characterized based on the geometry $[15,16]$ illustrated in Fig. 4(a). The yellow-colored block in a il in a black background is inferred as RA mixed with some amount of ferrite transformation (RA $+F)$. The remainder of the austenite grain surface is recognized as GB.

\subsection{Mikrostrukturne karakteristike}

Mikrostrukturni sastav austenitnih zrna u zoni FGHAZ čelika S700MC je okarakterisana na osnovu geometrije $[15,16]$ što je ilustrovano na slici 4a). Žuto obojena oblast na crnoj pozadini se poklapa sa RA, pomešanim sa izvesnim udelom ferita $(R A+F)$. Ostatak površina austenitnih zrna se prepoznaje kao GB. 
Inside the GB, the morphology of upper bainite is observed, as is some intergranular ferrite and carbide particles. The formation of intergranular ferrite is the result of a process of early phase transformation at high temperature, observed in the CCT diagram. This phase transformation is the cause of a displacive form of ferrite internally and around the austenite grain. On the S960QC side, austenite grains appear in Fig.(4b), which displays different behavior at a temperature of around 400 ${ }^{\circ} \mathrm{C}$. A grain boundary of ferrite develops along the austenite grain, and intergranular ferrite occupies a large part of the $G B$ and $R A$, which can be identified here as TMA (in green) on the figure. Tab. 2 presents fealures of some of the characterized microstructures of the studied materials. In S700MC, the shape of the bright dots inside the GB differs from that found in the GB of S960QC, which consists of bright lines. The structure of the GB of S960QC contains a lot of carbides(this can be justified by the lower cooling time) causing retained blocks of austenite in the grain.
Unutar GB, uočena je morfologija gornjeg beinita, kao i intergranularnog ferita i uključaka karbida. Formiranje intergranularnog ferita je rezultat procesa rane faze transformacije na visokim temperaturama, što je prikazano na $\mathrm{KH}$ dijagramu. Ova fazna transformacija je uzrok pojave ferita $\mathrm{u} i$ oko austenitnih zrna. Na strani čelika S960QC, austenitna zrna prikazana na Slici 4b) pokazuju drugačije ponašanje na temperaturama od oko $400^{\circ} \mathrm{C}$. Granice zrna ferita se razvijaju duž austenitnih zrna, i intergranularni ferit zauzima veliki deo GB i RA, koji je identifikovan kao TMA (zeleno) na slici.

Tabela 2. prikazuje izgled nekih mikrostruktura koje su karakterizovane $\mathrm{u}$ ispitivanim materijalima. U čeliku S700MC, oblik svetlih tačaka unutar GB se razlikuje od onih koje su pronađene u GB čelika S960QC, koji se sastoji od svetlih linija. Struktura GB čelika S960QC sadži dosta karbida (što može biti uzrokovano nižom brzinom hlađenja) koji uzrokuju zaostale blokove austenite u zrnu.
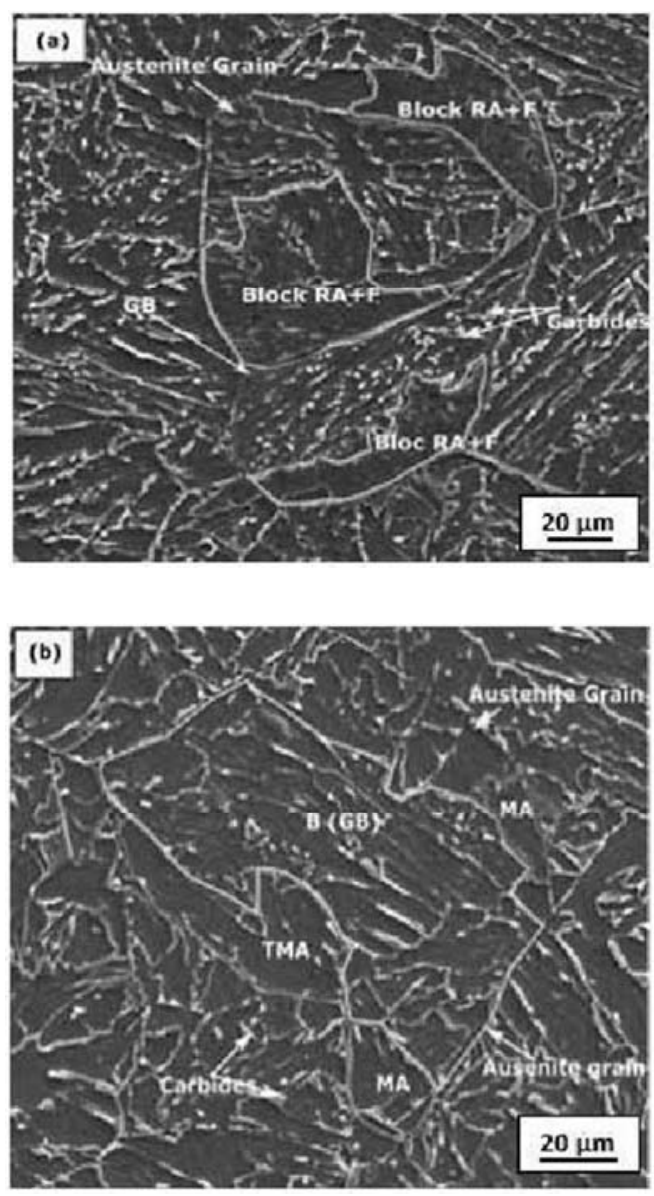

Figure 4. SEM micro images showing the composition of structures formed in the austenite grains: (a) microstructure of S700MC austenite grains; (b) microstructure of S960QC austenite grains

Slika 4. SEM mikro slike koje pokazuju struktura formiranih u austenitnim zrnima: a) mikrostrukture austenitnih zrna čelika S700MC; b) mikrostrukture austenitnih zrna čelika S960QC 
Table 2. Features of some microstructures in the CGHAZ of the studied materials (S700MC/S960QC)

Tabela 2. Karakteristike nekih mikrostruktura u zoni porasta zrna ZUTa (CGHAZ) ispitivanih materijala (S700MC/S960QC)

\begin{tabular}{|c|c|c|c|c|c|}
\hline Type of steel & $\begin{array}{l}\text { Structural } \\
\text { Feature }\end{array}$ & Characteristic & $\begin{array}{l}\text { Cooling at } 615 \\
{ }^{\circ} \mathrm{C}\end{array}$ & $\begin{array}{l}\text { Cooling at } 420 \\
{ }^{\circ} \mathrm{C}\end{array}$ & $\begin{array}{l}\text { Phase } \\
\text { transformation }\end{array}$ \\
\hline \multirow[t]{2}{*}{ S700MC } & & GBF & $\begin{array}{c}\text { Bainite + } \\
\text { Ferrite + } \\
\text { Cementite }\end{array}$ & & Bainitic Phase \\
\hline & & $\mathrm{RA}$ & & Bainite+ RA & Bainitic phase \\
\hline \multirow[t]{3}{*}{ S960QC } & & \multirow[b]{2}{*}{$\begin{array}{l}\text { Granular } \\
\text { Bainite }\end{array}$} & $470^{\circ} \mathrm{C}$ & $400^{\circ} \mathrm{C}$ & \multirow[t]{2}{*}{ Bainitic Phase } \\
\hline & & & $\begin{array}{c}\text { Bainite } \\
\text { transformation } \\
\text { at } 550^{\circ} \mathrm{C}\end{array}$ & & \\
\hline & & TMA & & RA to TMA & $\begin{array}{c}\text { Martensitic + } \\
\text { Retained } \\
\text { Austenitic }\end{array}$ \\
\hline
\end{tabular}

\subsection{Volume fraction of the phase}

Based on sampling of the SEM micrographs, measurements were carried out directly on the images of both materials [16], focusing on the area of the CGHAZ and FGHAZ. The cooling temperatures using in the analysis were respectively $615^{\circ} \mathrm{C}, 420{ }^{\circ} \mathrm{C}$ for S700MC and 470 ${ }^{\circ} \mathrm{C}, 400{ }^{\circ} \mathrm{C}$ for S960QC. The images were uploaded into the image processing software (ImageJ Pro) for identification of the different grain surfaces in the image. Fig. 5(a), 5(b) and 5(c) slow for S700MC, respectively, the original picture, the representation of the block GB (in black color), the description of the surfaces formed by deduction of retained austenite, (colored manually in yellow), and finally the infiltration ferrite + cementite, (colored in red). XT is the total area mapped, $X 1$ is the surface area occupied by GB (black color); X2 is the surface area of the RA (colored manually in yellow); and X3 is the space occupied by ferrite + cementite particles (in red). The ImageJ Pro software first determined the

\subsection{Zapreminski udeo faza}

Na osnovu uzoraka SEM mikrofotografija, merenja su vršena direktno na slikama za oba materijala [16], fokusirajući se na oblasti CGHAZ and FGHAZ. Temperature hlađenja koje su korišćene $u$ analizi iznosile su $615^{\circ} \mathrm{C}, 420^{\circ} \mathrm{C}$ za čelik S700MC i $470^{\circ} \mathrm{C}, \quad 400^{\circ} \mathrm{C}$ za čelik S960QC. Slike su procesuirane softverom za analizu slika (ImageJ Pro) sa ciljem identifikacije različitih površina zrna na slikama. Slike 5a), 5b) i 5(c) prikazuju za čelik S700MC redom: originalnu sliku mikrostrukture, izgled blokova GB (obojeno u crno), ocrtane površina formiranih odbitkom zaostalog austenita (obojeno ručno u žuto) i napokon prožimanje ferita + cementita (obojeno u crveno).

XT je ukupna mapirana površina, $X_{1}$ je površina $G B$ (u crnoj boji), $X_{2}$ je površina zaostalog austenite (obojena ručno u žutu boju), i $X_{3}$ je prostor koji zauzimaju čestice ferita + cementita (obojeno u crveno). Softver ImageJ Pro prvo određuje ukupnu površinu analiziranog uzorka XT, a nakon toga process merenja određuje $\mathrm{X}_{2}$ i $\mathrm{X}_{3}$. Sledeća relacija 
overall surface of the sampled $\mathrm{XT}$, after which a measurement process was used to discover $\mathrm{X} 2$ and $X 3$. The following relationship determines the volume fraction (X1) not occupied by the GB:

$X_{1}=X_{T}-\left(X_{2}+X_{3}\right)$ određuje zapreminski udeo $\left(X_{1}\right)$ koji nije zauzet sa GB:

$\mathrm{X}_{1}=\mathrm{X}_{\mathrm{T}}-\left(\mathrm{X}_{2}+\mathrm{X}_{3}\right)$
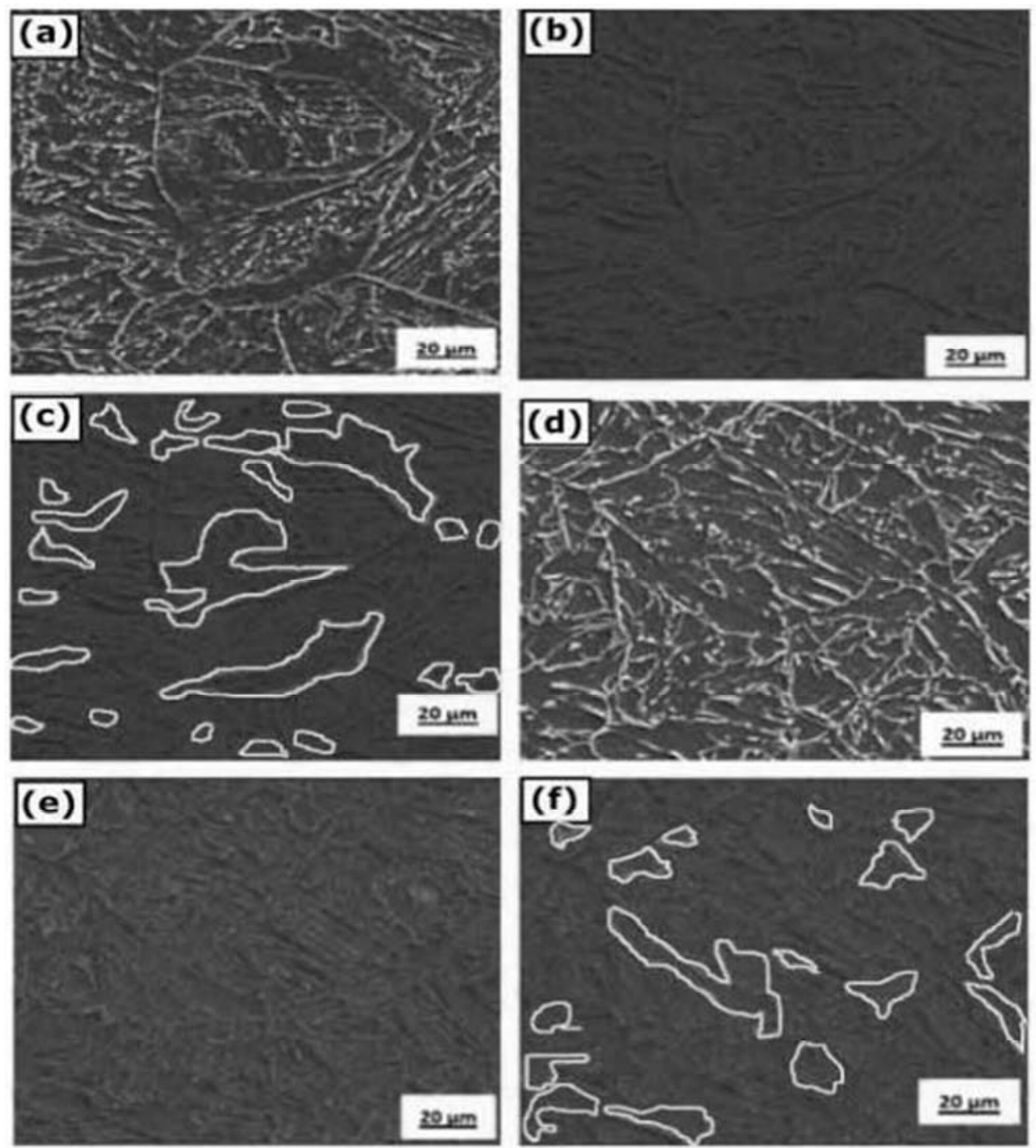

Figure 5. Evaluation of volume fraction of GB, TMA, RA, and ferrite using ImageJ Pro software: (a) original micrograph of S700MC; (b) darker area to measure the GB, ferrite, and cementite, colored in red; (c) geometries to measure the volume fraction of RA, yellow; (d) original micrograph of S960QC; (e) darker area to measure the GB volume fraction, and red zone to measure the volume fraction of ferrite; and (f) geometries to measure the TMA, yellow

Slika 5. Određivanje zapreminskog udela GB, TMA, RA, i ferita primenom softvera ImageJ Pro: a) originalna microslika čelika S70OMC; (b) tamnija oblast za merenje GB, ferita, i cementita, obojena u crveno; (c) geometrija za merenje zapreminskog udela RA, žuta; (d) originalna microslika čelika S960QC; (e) tamnija oblast za merenje GB zapreminskog udela, i crvena zona za merenje zapreminsko udela ferita; $i$ (f) geometrija za merenje TMA, žuto

The same measurement method was applied for the S960QC steel. The phase transformation was identified mainly as cooling time GB and the TMA has temperatures of $470{ }^{\circ} \mathrm{C}$ and $400{ }^{\circ} \mathrm{C}$ respectively. Fig. 4(a) presents the original SEM image. $X T$ is the total area of the sample map; $X_{1}$ is the part occupied by the GB (Black) measured in Fig. 4(b); $X_{2}$ represents the ferrite particles and cementite (in red) obtained on the same figure as
Isti metod merenja je primenjen za čelik S960QC. Fazne transformacije su identifikovane kao $\mathrm{GB}$ i TMA pri hlađenju sa temperatura $470^{\circ} \mathrm{C}$ and $400^{\circ} \mathrm{C}$. Slika 4a) prikazuje originalnu SEM sliku. XT je ukupna površina uzorkovane mape; $X_{1}$ je deo zauzet sa GB (crno) mereno na Slici $4 b$ ); $X_{2}$ predstavlja feritne čestice i cementit (crveno) dobijeno sa iste slike kao $X_{2}$; i $X_{3}$ je oblast TMA merena ručno softverom ImageJ Pro. Rezultati 
$\mathrm{X}_{2}$; and $\mathrm{X}_{3}$ is TMA measured from ImageJ Pro software manually. The results of the analysis giving the fraction volumes as a function of the temperature points identified are presented in Fig. 6. Fig. 6(a) shows the maximum value of the volume fraction of GB is about $70 \%$, which is observed at a temperature of $500{ }^{\circ} \mathrm{C}$. Fig. (6b) presents two results separately; the fraction volume of the ferrite, which has a maximum value of $60 \%$ at a temperature of $615{ }^{\circ} \mathrm{C}$ corresponding to the start of solidification of the weld sample, and the fraction volume of $\mathrm{RA}$ with a maximum value at $25 \%$ at $420{ }^{\circ} \mathrm{C}$. Fig. 6 (c) shows volume fraction of GB produced in S960QC, which peaks at around $60 \%$ at a temperature of $470{ }^{\circ} \mathrm{C}$. Fig. $6(\mathrm{~d})$ has two graphs, which show the respective volume fractions of ferrite and TMA. As found in previous data, the volume fraction of ferrite increases when the temperature is still high, at $58 \%$, and decreases as it decreases. During the transformation, incomplete processing inside the austenite grain will translate into $R A$, which has a reduced temperature change to TMA, which is estimated to be $34 \%$ to its maximum value $\left(400^{\circ} \mathrm{C}\right)$.

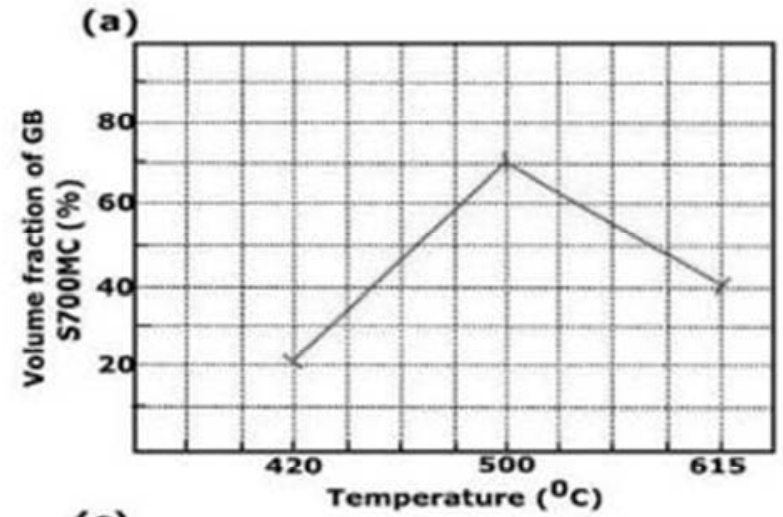

(c)

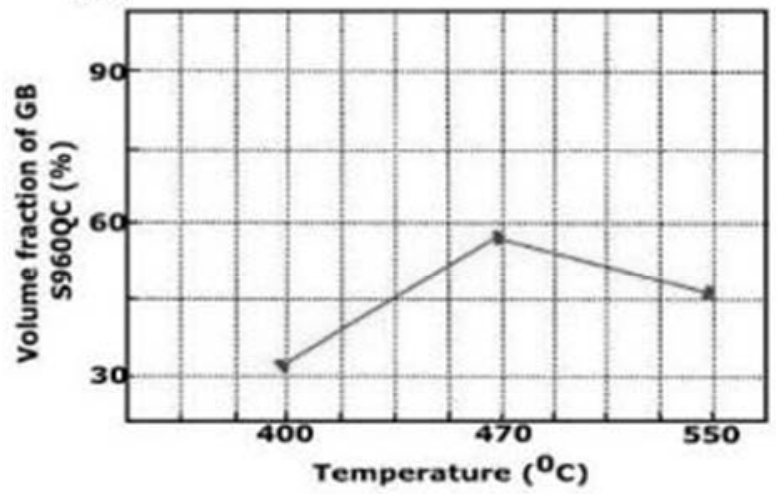

analize prikazani na Slici 6 . daju zavisnost zapreminskih udela od identifikovanih temperaturnih tačaka.

Slika 6a) prikazuje maksimalnu vrednost zapreminskog udela GB koja iznosi oko $70 \%$ i koja je konstantovana na temperaturi od $500^{\circ} \mathrm{C}$. Na Slici 6b) prikzana su dva pojedinačna rezultata, zapreminski udeo ferita koji ima maksimalnu vrednost od $60 \%$ na temperaturi od $615^{\circ} \mathrm{C}$, koja odgovara početku očvršćavanja zavarenog uzorka, kao i zapreminski udeo RA sa maksimalnom vrednošću od $25 \%$ na $420^{\circ} \mathrm{C}$. Slika 6c) prikzuje zapreminski udeo GB nastalog u čeliku S960QC, čiji je najviša vrednost od oko $60 \%$ na temperaturi od $470^{\circ} \mathrm{C}$. Slika 6 d) ima dva grafika koji pokazuju zapreminske udele ferita i TMA. Kao što je pronađeno u prethodnim podacima, zapreminski udeo ferita raste dok je temperatura visoka, i iznosi $58 \%$ i opada kada temperature opadaju. Za vreme transformacije, unutar austenitnih zrna se odvija nekompletni proces pretvaranja u RA, koje ima smanjenu temperaturnu promenu ka TMA, koji je procenjen na $34 \%$ do njene maksimalne vrednosti $\left(400{ }^{\circ} \mathrm{C}\right)$.
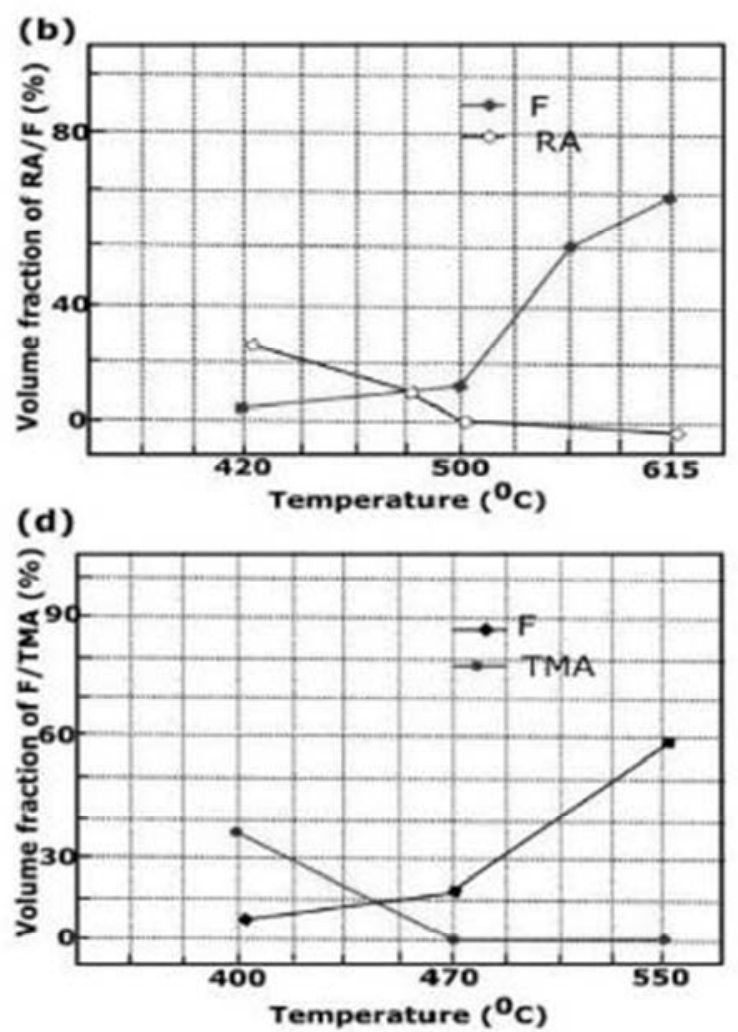

Figure 6. Volume fraction of phase transformations in studied both materials: (a) volume fraction of GB of S700MC; (b) volume fraction of RA and F; (c) volume fraction of GB of S960QC; (d) volume fraction of TMA/F of S960QC

Slika 6. Zapreminski udeo faznih transformacija kod oba ispitivana materijala: a) zapreminski udeo GB čelika S700MC; b) zapreminski udeo RA i F; c) zapreminski udeo GB čelika S960QC; d) zapreminski udeoTMA/F čelika S960QC 


\subsection{Precipitates in the welded sample using EDS Analysis}

For analysis of the micro-alloy elements, EDS was applied to two sides of the weld. Fig. 7 shows the mapping and spectra records for alloy elements in S700MC and Fig. 8 the same information for S960QC. The EDS was calibrated at a voltage up to $15 \mathrm{kV}$ with mapping at $20 \mathrm{kV}$, and the resolution of the image was 1024 by 768 , with a magnification of $2.5 \mu \mathrm{m}$. The data was recorded in weight \%, which presents the percentages of $\mathrm{C}$ transforms, $\mathrm{Si}, \mathrm{Cr}, \mathrm{Mn}, \mathrm{Fe}, \mathrm{Ni}$, and Mo. Tab. 3 shows the proportions of the weights of the micro-elements of alloys obtained. An absence of $\mathrm{Ni}$, Mo in the microstructure of the $S 960 Q C$ can be seen, and an increase in the weight \% of $\mathrm{Mn}$. These three alloy elements play a significant role in the relation between the microstructure behavior and mechanical properties of the weld joint, particularly as regards the HAZ.
3.3 Talozi u zavarenim uzorcima koji su određeni pimenom EDS analize

Za analizu mikro legirajućih elemenata primenjena je EDS analiza na obe strane zavarenog spoja. Slika 7. prikazuje mapiranje i zapis spectra za legirajuće elemente u čeliku S700MC, a na Slici 8. za čelik S960QC. EDS je kalibrisan do $15 \mathrm{kV}$ sa mapiranjem pri $20 \mathrm{kV}$, a rezolucija slika je bila $1024 \times 768$, sa uvećanjem od $2.5 \mu \mathrm{m}$. Podaci su zabeleženi u težinskim \%, i oni predstavljaju procente transformacije $\mathrm{C}, \mathrm{Si}, \mathrm{Cr}, \mathrm{Mn}, \mathrm{Fe}, \mathrm{Ni}$ i $\mathrm{Mo}$. Tabela 3. prikazuje dobijene težinske udele mikro elemenata ovih legura. Može se konstatovati odsustvo Ni i Mo u mikrostrukturi čelika S960QC, kao i povećanje težinskih \% mangana. Ova tri legirajuća elementa igraju glavnu ulogu u odnosu između mikrostruktura i mehaničkih osobina zavarenog spoja, posebno ZUTa.

Table 3. Micro-alloy elements composition in both sides of the dissimilar welded joint (S700MC/S960QC)

Tabela 3. Sastav mikro legirajućih elemenata sa obe strane zavarenog spoja različitih čelika (S700MC/S960QC)

\begin{tabular}{|c|c|c|c|c|c|c|c|c|}
\hline Elements (\%) & C & Si & Cr & Mn & Fe & Ni & Mo & \% \\
\hline S700MC (CGHAZ area) & 3.3 & 0.6 & 0.5 & 1.6 & 92.2 & 1.3 & 0.4 & 100 \\
\hline S960QC (CGHAZ area) & 3.4 & 0.3 & 0.1 & 1.8 & 94.2 & - & - & -100 \\
\hline
\end{tabular}

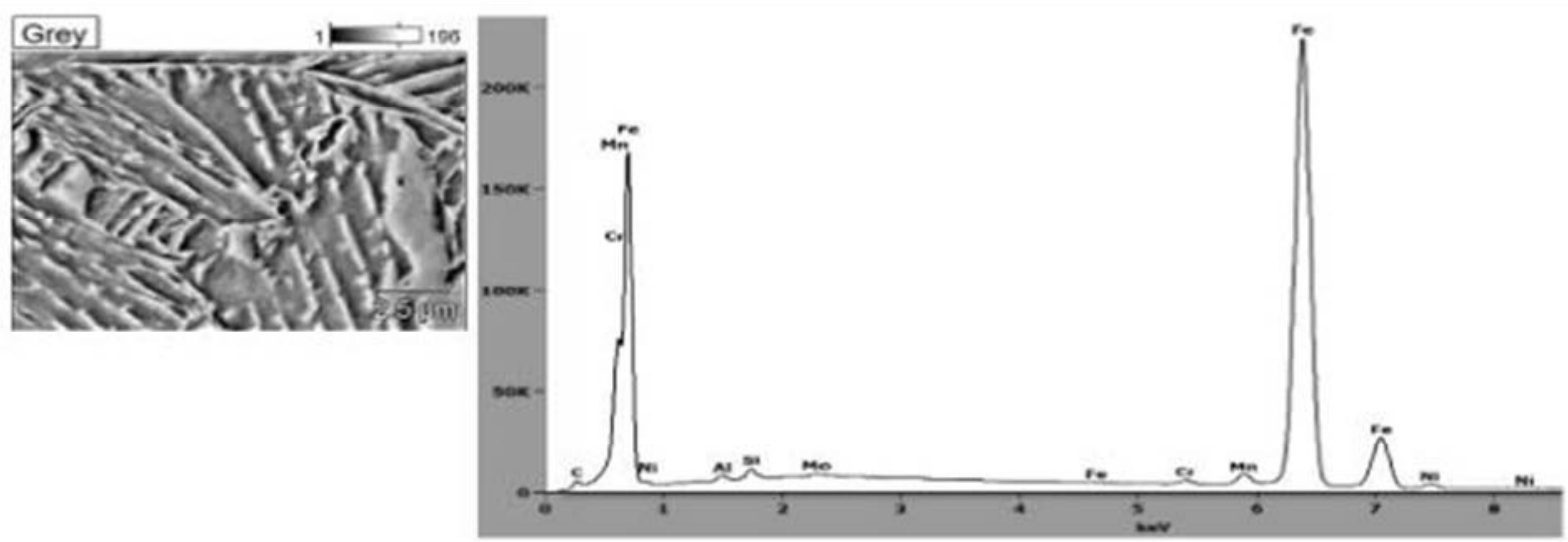

Figure 7. EDS analysis of the composition of alloy elements in S700MC

Slika 7. EDS analiza sastava legirajućih elemenata u čeliku S700MC
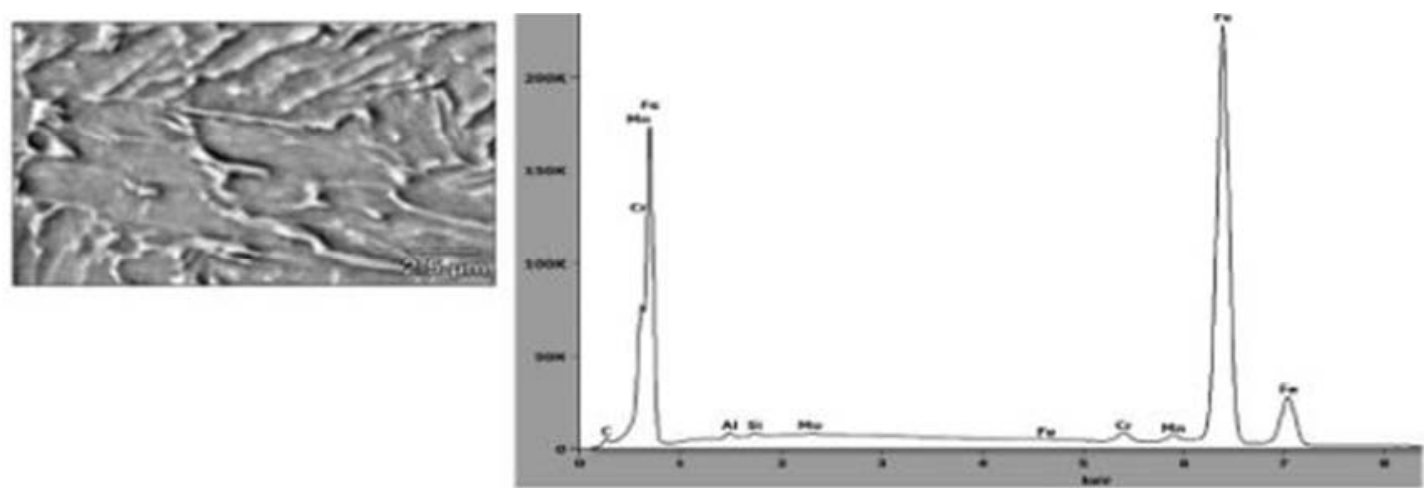

Figure 8. EDS Analysis of the composition of alloy elements in S960QC

Slika 8. EDS analiza sastava legirajućih elemenata u čeliku S960QC 
The respective weights of $\mathrm{Mn}, \mathrm{Ni}$, Mo obtained were 1.6, 1.3 and 0.4 for S700MC, and 1.8, 0,0 for S960QC. The absence of $\mathrm{Ni}$ in the CGHAZ of S960QC can cause softening in this area even though there is a small increase in the weight \% of $\mathrm{Mn}$. As observed in the evaluation of the phase transformations, the rise in $\mathrm{Mn}$ promotes the appearance of martensite at the end of the transformation phase of S960QC. In the S700MC, the formation of alloy elements of $\mathrm{Mn}, \mathrm{Ni}$ and $\mathrm{Mo}$ enable composition of upper bainite at $615^{\circ} \mathrm{C}$ and TMA at $400{ }^{\circ} \mathrm{C}$, as indicated in the previous results showing a high-volume fraction of GB (GB $=70 \%$ ). This high value of GB resulting from the appearance of alloy elements is the source of softening in the CGHAZ, which was confirmed during the hardness analysis, and shows the link between the microstructure behavior of the weld joint and the mechanical behavior of the weld. Equation 2 estimate the increasing of the strain zones of both materials, which lead to reinforced the precipitation strengthening $(\mathrm{l})$ in the area analyzed using EDS.

$\rho_{p}=\frac{0.538 G b f_{G B}^{1 / 2}}{X} \ln \left(\frac{X}{2 b}\right)$

Where $G$ indicates the modulus of elasticity (in $\mathrm{MPa}), \mathrm{b}(\mathrm{mm})$ is the vector of Jan burgers [17], is the volume fraction of particle GB of both materials, and finally $X$ is the precipitation diameter of the $G B$ transformation into the austenite grain. After different evaluations, it is notice an increase in yield strength compared to the experimental values, which can be evaluated tensile test. The for example, the precipitation strengthening ( $\rho p)$ obtained was $23.2 \mathrm{MPa}$ for S700MC, and $27 \mathrm{MPa}$ for S960QC respectively.

\section{Conclusions}

Phase evaluation of the transformation of bainite, ferrite, and martensite in the HAZ of a dissimilar weld joint of dissimilar high strength steels (S700MC/S960QC) welded with X96 filler material was carried out in this study. SEM and EDS analysis were used to identify the different phase transformations, quantify the volume fractions, and evaluate the composition of the alloy elements in the weld.

1. CCT diagrams indicated phase transformations in S700MC of ferrite from $670{ }^{\circ} \mathrm{C}$ to $615{ }^{\circ} \mathrm{C}$ and bainite from $615^{\circ} \mathrm{C}$ to $500{ }^{\circ} \mathrm{C}$.
Dobijeni su odgovarajući težinski \% $\mathrm{Mn}, \mathrm{Ni}$, Mo u iznosu od 1.6, 1.3 and 0.4 za čelik S700MC, a za čelik S960QC iznosili su 1.8, 0, 0. Osustvo $\mathrm{Ni} \mathrm{u}$ zoni CGHAZ čelika S960QC može uzrokovati omekšavanje u toj oblasti bez obzira na malo povećanje težinskog \% Mn. Kao što je konstatovano tokom faznih transformacija, povećanje sadržaja $\mathrm{Mn}$ potpomaže pojavu martenzita na kraju transformacija faza u čeliku S960QC. U čeliku S700MC, prisustvo elemenata $\mathrm{Mn}, \mathrm{Ni}$, i Mo omogućava stvaranje gornjeg beinita na $615^{\circ} \mathrm{C}$ i TMA na $400^{\circ} \mathrm{C}$, kao što je prikazano prethodnim rezultatima koji pokazuju visok zapreminski udeo GB (GB = 70\%). Ova visoka vrednost GB kao rezultat pojave legirajućih elemenata na lokaciji omekšavanja u zoni CGHAZ, što je potvrđeno analizom tvroća, pokazuje vezu između ponašanja mikrostruktura zavarenog spoja i ponašanja mehaničkih osobina zavarenog spoja.

Jednačina 2 prikazuje povećanje zona deformacije kod oba materijala, koje dovodi do taložnog ojačavanja u oblasti koja je analizirana primenom EDSa.

$\rho_{p}=\frac{0.538 G b f_{G B}^{1 / 2}}{X} \ln \left(\frac{X}{2 b}\right)$

Gde G označava modul elastičnosti (u MPa), b $(\mathrm{mm})$ je vector Jan burgers [17], $f$ je zapreminski udeo čestica GB kod oba materijala i konačno $X$ je prečnik transformacija za GB transformacije u austenitnom zrnu. Nakon proračuna uočava se povećanje granice razvlačenja u poređenju sa eksperimentalnim vrednostima, dobijenim ispitivanjem zatezanjem. Na primer, dobijena je vrednost za taložno ojačavanje $\left(\rho_{p}\right)$ od $23.2 \mathrm{MPa}$ za čelik S700MC, i 27 MPa za čelik S960QC.

\section{Zaključci}

$U$ ovom istraživanju izvršena je procena faznih transformacija beinita, ferita, i martenzita u ZUTu zavarenog spoja različitih materijala $\mathrm{i}$ to čelika visoke čvrstoće (S700MC/S960QC) zavarenih sa dodatnim materijalom X96. SEM i EDS analize su primenjene za identifikaciju različitih fazing transformacija, kvantifikaciju zapreminskih udela i za procenu sadržaja legirajućih elemenata u zavarenom spoju.

1. $\mathrm{KH}$ dijagrami prikazuju fazne transformacije $\mathrm{u}$ čeliku S700MC i to za ferit od $670^{\circ} \mathrm{C}$ do $615^{\circ} \mathrm{C}$ i za beinit od $615^{\circ} \mathrm{C}$ do $500^{\circ} \mathrm{C}$. 
2. In the case of S960QC steel, there is bainite transformation from $550{ }^{\circ} \mathrm{C}$ to $470{ }^{\circ} \mathrm{C}$, and martensite from $470{ }^{\circ} \mathrm{C}$ to $400{ }^{\circ} \mathrm{C}$.

3. SEM images confirmed the ascendency of $G B$ transformation for cooling time to $500{ }^{\circ} \mathrm{C}$, allowing evaluation of the volume fraction of $\mathrm{GB}$ as $70 \%$ $\left(500{ }^{\circ} \mathrm{C}\right)$, ferrite as $60 \%\left(615^{\circ} \mathrm{C}\right)$ and RA of almost $23 \%$ at $420^{\circ} \mathrm{C}$.

4. In the austenite grain of the S960QC steel, there was development of GB with a high volume fraction of $70 \%$ at $470{ }^{\circ} \mathrm{C}$, then some amount of ferrite cementite around and inside the austenite grain, evaluated as $40 \%$ at $550^{\circ} \mathrm{C}$, which later transformed into TMA at $400{ }^{\circ} \mathrm{C}$.

5. EDS analysis showed the absence of alloy elements such as $\mathrm{Ni}$ and $\mathrm{Mo}$ in the CGHAZ of S960QC, but their presence in the same area of the S700MC (1.3Ni, 0.4Mo).This finding confirms the correlation between the microstructural analyses suggesting softening in the HAZ and the mechanical behavior of the sample.

6 . The noticeable presence of $1.3 \mathrm{Ni}, 0.4 \mathrm{Mo}$, and $1.6 \mathrm{Mn}(\mathrm{S} 700 \mathrm{MC})$ confirmed the temperature rise in the HAZ, as did the production of bainite with significant intrusion of ferrite and cementite.

The different compositions of alloy elements on different side of the dissimilar weld may produce different behaviors in the HAZ of the weld, for example, there may be an increase in toughness on the S960QC side caused by the absence of alloy elements such as $\mathrm{Ni}$ and Mo. It is essential to evaluate the amount of $\mathrm{Mn}$ found in the steel, in this case $1.8 \mathrm{Mn}$, as increased strength can expose the weld to a higher risk of brittle fracture.

\section{Acknowledgments}

The authors gratefully acknowledge financial support from the Finnish Cultural Foundation (No. 190749), the EU project Energy-efficient systems based on Renewable Energy for Arctic Conditions (EFREA) (Grant number K51054).

\section{Conflicts of Interest}

The authors declare no conflicts of interest.
2. U slučaju čelika $S 960 Q C$, beinitna transformacija je od $550^{\circ} \mathrm{C}$ do $470^{\circ} \mathrm{C}$, i martenzitna od $470^{\circ} \mathrm{C}$ do $400^{\circ} \mathrm{C}$.

3. Slike SEM analize potvrđuju dominaciju transformacije GB za vreme hlađenja do $500^{\circ} \mathrm{C}$, omogućavajući procenu zapreminskog udela GB od oko $70 \%\left(500^{\circ} \mathrm{C}\right)$, ferrite oko $60 \%\left(615^{\circ} \mathrm{C}\right)$ i RA od skoro $23 \%$ na $420^{\circ} \mathrm{C}$.

4. U austenitnim zrnima čelika S960QC stvarao se GB sa visokim zapreminskim udelom od $70 \%$ na $470^{\circ} \mathrm{C}$, zatim izvesni udeo ferita oko i unutar austenitnih zrna, u količini oko $40 \%$ na $550^{\circ} \mathrm{C}$, koji je kasnije transformisan $u$ TMA na temperaturi od $400^{\circ} \mathrm{C}$.

5. EDS analiza pokazuje odsustvo legirajućih elemenata kao što su Ni i Mo u zoni CGHAZ čelika S960QC, ali i prisustvo u pojedinim zonama čelika S700MC (1.3Ni, 0.4Mo). Ovi nalazi potvrđuju korelaciju između mikrostrukturnih analiza predpostavljajući omekšavanje u ZUTu i mehaničkog ponašanje uzorka.

6. Uočljivo prisustvo elemenata $1.3 \mathrm{Ni}, 0.4 \mathrm{Mo} \mathrm{i}$ $1.6 \mathrm{Mn}$ (S700MC) potvrđuje da sa porastom temperature u ZUTu nastaje beinit sa značajnim nastajanjem ferita i cementita.

Različit sadžaj legirajućih elemenata na različitim stranama zavarenog spoja različitih metala, može izazvati različito ponašanje u ZUTu zavarenog spoja, na primer može doći do povećanja žilavosti na strani čelika S960QC uzrokovano odsustvom legirajućih elemenata kao što su Ni i Mo. Zato je važno odrediti udeo $\mathrm{Mn}$ u čeliku, u ovom slučaju $1.8 \mathrm{Mn}$, pošto povišena čvrstoća može zavareni spoj da izloži višem riziku ka krtom lomu.

\section{Zahvalnica}

Autori se zahvaljuju na finansiskoj podršci od strane Finnish Cultural Foundation (No. 190749), zatim EU projektu Energy-efficient systems based on Renewable Energy for Arctic Conditions (EFREA) (Grant number K51054).

\section{Konflikt interesa}

Autori potvrđuju da nema konflikta interesa. 


\section{References}

[1] Mvola B, Kah P, Martikainen $Y$, and Suoranta R 2015 Reviews on Advanced Materials Science 44, pp. 146-159.

[2] Njock B. F. Kah P. Mvola B. and Pavel L. 2019 Review on Advanced Materials Science, 58(1), pp. 38-49.

[3] Pirinen M. Martikainen Y. Pavel L. Karkhin V. and Ivanov S 2015 Welding International 2, pp. 1417.

[4] Gorka J. 2016 Material and Technology 50 pp. 617-621.

[5] Yasar U. and Hamdullah C. 2015 Advances in Structural Engineering and Mechanics (ASEM15), Incheon, Korea.

[6] Lambert A. Drillet J. Gourgues F Sturel T. and Pineau A. 2000 Science and Technology of Welding and Joining 5(3), pp. 168-173.

[7] Siltanen J. and Tihinen S. 2012 Journal. of Laser Applications. doi.org/10.2351/1.5062489.

[8] Kulakov M. Poole W. and Militzer M. 2014 ISIJ International, 54(11) pp. 2627-2636,.
[9] Zajac S. Schwinn V. and Tacke H. 2005 Materials Science Forum 500-501 pp. 387-394.

[10] Van Bohemen S.M.C. Sietsma J. 2010 Materials Science and Engineering A 527 pp. 66726676.

[11] Mingxing Z. Guang X. Haijiang H. Qing Y. and Junyu T. 2017 Steel Research International 88(7) pp. 1-7.

[12] Seppälä O. Pohjonen A. Kaijalainen A. Larkiola J. and Porter D. 2018 Procedia Manufacturing 15, pp. 1856-1863.

[13] Gorka J. 2014 Metals 837 pp. 375-380.

[14] Tasalloti H. Kah P. Martikainen J. 2017 Material and Characterization 123 pp. 29-41.

[15] Navarro-Lopez A. Hidalgo J. Sietsma J. and Santofimia M. 2017 Materials Characterization 128 pp. 248-256.

[16] Junyu T. Guang X. Mingxing Z. and Haijiang $H$. 2018 Steel Research International 1700469 pp. 110.

[17] Shu Y. Xianghua L. Taosha L. Jingqi C. and Yang Z. 2019 Steel Research International, 1800257 pp. 1-10.

Podsećamo Vas da je članarina za 2021.g ostala nepromenjena i iznosi 3500,00 dinara.

Uplatom članarine stičete pravo na GRATIS godišnje izdanje

časopisa "ZAVARIVANJE I ZAVARENE KONSTRUKCIJE"

Tekući račun DUZS: 325-9500600002588-46

Informacije:

to +381 (11) 2420-652 